\title{
NARRATIVE FUNCTION OF THE APOCALYPSE
}

Young Jang

University of Stellenbosch

\begin{abstract}
Apocalyptic stories, as rhetorical-symbolic narratives, urge the hearer to view his/her historical situation afresh and to act accordingly. To find out how this happens, the transforming power of the Apocalypse has been analysed according to two contexts: the literary and the socio-historical. Through his apocalyptic narrative, John wants to illumine the reality behind the context of the audience and to transform them into a Christian community with a shared vision and conviction. In a broad sense, the book is concerned with the author's understanding of God (narrative theology), and how it can be related to the audience's response (narrative function). From this study of the rhetorical function of the book, we may conclude that John tries to persuade the evildoers to repent and the faithful to remain witnesses in the world.
\end{abstract}

- This article is a tribute to my study leader, Prof HJB Combrink.

\section{General}

The content of his message is, in fact, the purpose declared by God. Here, "word" (1:2)

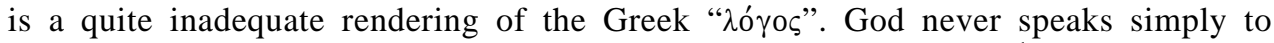
convey information, but always to achieve results (cf. Caird 1966:11). ${ }^{1}$

We are here interested in the transforming power of John's narrative. Apocalyptic stories are generally designed to shape the imagination of the hearer, to allow one to view one's historical situation differently and to act in a new way. Apocalyptic narratives, being revelatory in a basic sense, lead us to see the world anew by reversing our expectations. The Apocalypse also serves to alter the audience's perception of the world - to transform them from victims of Roman oppression, for example, into victors over universal evil forces.

How does this happen? We will investigate the transforming power of the Apocalypse in two contexts: the literary and the socio-historical context. The first part deals with a narrative strategy to persuade the audience - reversal - that is related to the aim of John's narrative to transform the listeners' improper or problematic view of a theme into a proper view of that theme. Insofar as it tries to persuade the audience, John's narrative can be called rhetoric. The latter part deals with the transforming power of John's narrative when it is used in the external (socio-political) context.

\section{Narrative strategy effecting transformation, in the literary context}

Reversal, which happens at the beginning and at the end of the story (Abrams 1999:227), is an important narrative strategy through which John leads the audience to have a different viewpoint of their historical situation. Patte (1990:14-15) points out that in narrative, the inverted parallelisms are found easily in the way that a theme which is problematic at the introduction is resolved at the end of the story. The reversal

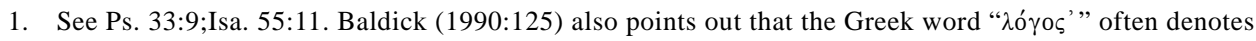
an ultimate principle of truth or reason and in Christian theology it refers to the Word of God as the origin and foundation of all things. 
strategy seems to be well suited to the Apocalypse because John tries to persuade the audience through the visionary world story where they are victors; by contrast, in their real situation, they are dominated by evil forces.

\section{Reversal at the beginning and end of John's narrative}

Reversal occurs when the audience reaches the end of John's narrative, they come to face the truth lying behind everything in the status quo dominating them.

- Firstly, what does John try to reverse?

The theme is stated as either a problem or a question in the introduction. The author uses it as an issue of interest to the envisioned reader whose knowledge must now be revised (Patte 1990:14).

There is no doubt that the theme of John's narrative is closely related to the historical situation/exigency of his readers/audience. In particular, 1:9 "I, John, your brother and companion in the suffering and kingdom and patient endurance that are ours in Jesus...." gives an indication of their historical situation and reveals that John is sharing this experience with them. Hence his concern about this matter which prompts him, as a leader of the contemporary Christians, to write to them.

But describing this implied historical situation is not as simple as might be thought, as can be seen from the different opinions among scholars in this respect. We should therefore use a multi-faceted approach to try and uncover as much as is exegetically possible.

Most scholars agree that the latter part of Domitian's reign is the most likely social context for the Apocalypse. However the book itself is not sufficiently explicit about time and date to establish a specific social, historical context (cf. Gager 1975:115-142; Collins 1984:84-110; Schüssler Fiorenza 1985:181-199).

- Secondly, how does the reversal take place in John's narrative? According to Patte (1990:14) this occurs through the inverted parallelism between the introduction and the conclusion of the narrative: "the goal of the discourse is to transform the reader's old knowledge (an improper or problematic view of a theme, formulated in the introduction) into a new knowledge (a proper view of that theme, presented in the conclusion)."2

A comparison of the beginning and end of the Apocalypse, then, would allow us to identify inverted parallelisms between them: the situation presented in the introduction is transformed by the time one reaches the conclusion. It is in the introduction of John's narrative (1:9 - 3:21) that we find John's contemporary churches' as well as John's suffering experience from within and without. But when we reach the conclusion of the narrative (17:1 - 22:5), we find the situation between the Lamb's followers and Satan's followers (the evildoers) totally reversed. ${ }^{3}$

2. The usage of figurative language such as metaphor and symbol is distinguished in the Apocalypse. The symbolic-poetical work would be a powerful means for persuading the readers/audience - especially when the audience experiences the sense of fracture and abrasion between what happens now and what is promised (cf. Patte 1990:14-15).

3. In those days, the Christians were excluded from Jewish and Greek institutions; they were dragged before the earthly court, but now they stand before the throne and before the Lamb - that is the heavenly court; they suffered from emperor worship, but now they worship the real Master; then, Jerusalem was destroyed, but now the new Jerusalem is established; formerly, they underwent persecution, Antipas was killed and John himself was exiled but now they are saved and enjoy their bliss under God's tabernacle. On the other hand, Satan and all his followers (represented by the beasts, 


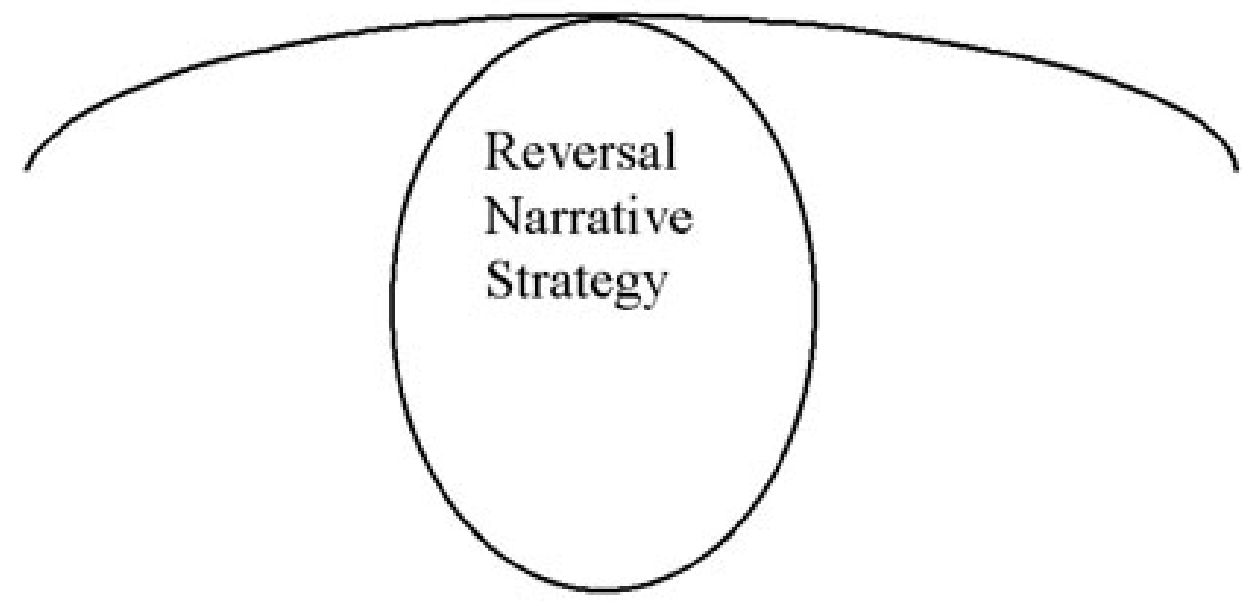

Fig. 1

In the meanwhile, for this reversal, what happens in the text between the beginning and the conclusion of the narrative? ${ }^{4}$ According to Lowry's theory (1980), the reversal of the Apocalypse takes place as follows: ${ }^{5}$

- Firstly, the introduction of the Apocalypse (1:1-8) functions to upset the equilibrium of the listeners in such a way as to engage them in the narrative theme. We can assume that most of the audience/readers are in a neutral state, mentally, as the experience begins, even if some appear eager to be engaged, others reluctant. John draws them into a world of his own making.

There is always an important discrepancy, exigency or problem which is the issue. ${ }^{6}$ These are found especially in the letter-series vision that corresponds to the setting or situation of the plot of the Apocalypse $(1: 9-4: 11)$. "Generally, the context itself is a supercharged one which provides so great an exigency [italics mine] that it becomes unnecessary to worry oneself with cultivation" (cf. Lowry 1980:78).

the evil doers, the wayward, the false prophets) are judged at the end of the narrative, although they seem to rule over Christians on earth at the beginning of the narrative. "The New Jerusalem" would be an epitomized symbol of the promise fulfilled by Jesus (chs 21-22). These changes cause a rhetorical effect: it is expected that the readers/audience throughout John's narrative will be persuaded to revert (or change or correct) their attitude or ideas towards the present dominant evil powers and also to recover/encourage/strengthen their faith or their identity as Christians.

4. I am indebted to Lowry (1980) for this reversal strategy, even though he applies it in the context of the homiletical plot: the sermon as narrative art form. Actually, the Apocalypse can be thought of as a sermon in the worshipping context of a congregation. See Jang (2001:121-150) on the narrative plot of the Apocalypse used here.

5. Cf. Jang (2001:121-150) on the narrative plot of the Apocalypse used here.

6. A narrative has a plot devised by the author, which has as its major ingredient a sensed problem (Lowry 1980:150). 
- Secondly, through the process, John moves from the initial upsetting of the equilibrium to the complication of the plot (5:1-11:19) - continually increasing the tension experienced in the initial discrepancy. However, something is "up in the air" - an issue not solved (6:9-11). Suspense, one of the narrative strategies, plays an important role in this phase. One cannot breathe easily until some solution is reached. The ongoing suspense/uncertainty provides the existential reason for continuing to hear/read on.

As a plot unravels it arouses expectations in the audience or reader about what is to happen and how characters will react. When a concerned reader is uncertain about what is going to happen, especially to those characters with whom the reader is sympathetically involved, he or she experiences suspense. If what happens runs contrary to our expectations, we experience surprise. The dynamic interplay of suspense and surprise is a chief source of vitality in a traditional plot.

- Thirdly, all problem-solving processes look for some missing link, some explanation that accounts for the problematic issue. When found, the missing link is the bridge from problem to solution. At the beginning of the resolution $(12: 1-$ $16: 21)$, Jesus is introduced as the missing link to solve the problem, the very same Jesus who the audience may have doubted/forgotten because nothing has happened since his ascension and such a long time has lapsed without the second coming he had promised them, taking place. In other words, the mythical episodes about Jesus, his birth (12:1-6), and his death and ascension (12:7-12) imply that Jesus is going to appear as the way to resolve all problems. The most effective surprise is "one which turns out, in retrospect, to have been grounded in what has gone before, even though we have hitherto made the wrong inferences from the given facts of circumstance and character" (Abrams 1999:225). An example of such a misconception is that John's audience might consider the Roman Empire as the strongest kingdom on earth and also false prophets in the church or Roman Emperors as all-powerful.

The human predicament moves with increasingly felt "necessity" toward some kind of release, toward the revealing of the missing link, "Jesus." Once disclosed, matters are seen in a different light. It is not quite what one had expected, and a solution "arrives" from an unexpected source, which turns things upside down. Once the clue to the resolution is articulated, the hearer is ready to receive the word. Now we are expected to discover how the eternal gospel of/about Jesus Christ (14:6) meets the human predicament.

- Fourthly, this phase corresponds to the evaluation of the plot of the Apocalypse (17:1 - 22:5), which contains the emotional reaction with respect to the previous narration (Van Dijk 1980:115), but also summarizes/introduces the gospel as an ultimate solution of the hitherto unsolved problem. Only recourse to God's answer in other words, the gospel, the good news of/about Jesus Christ - can be the ultimate solution to the human predicament. Once Jesus has been suggested as the ultimate clue to the resolution, the narrative context is ripe for the experiencing of the gospel. John is ready to announce the good news, while the audience would also be prepared to accept it. The previous stages are intended to prepare the way so that the gospel is effectively proclaimed. When the gospel is proclaimed, we can expect a result, a change of viewpoint or attitude of a hearer/reader having been in a

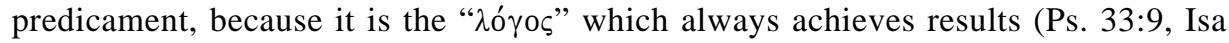


55:11). Whatever the issue, this phase reveals a new door opened, the new possibility occasioned by the gospel.

"Behold, I make all things new" (21:5).

- Finally, with the gospel having been proclaimed, we are now ready to ask: what conesquences can be anticipated as a result of this intersection of the gospel and the human predicament (22:6-21)? The critical matter left for explication has to do with the future - now made new by the gospel. John asks, in the light of the gospel, what can be expected, should be done, or is now possible? It anticipates how life can now be lived. "Human response is subsequent to that experience of gospel - and consequent of it" (Lowry 1980:69). The narrated word has brought the audience/readers into a new life by its announcement of what God has done and is doing - the good news. This means that the central issue of John's narrative is the proclamation of the good news. The anticipation of the consequences of hearing the gospel could be varied, but must be predicated on the new situation created by the gospel. The audience is persuaded to make a new choice, perhaps never before made, such as worshipping only God instead of earthly gods. Now the possible

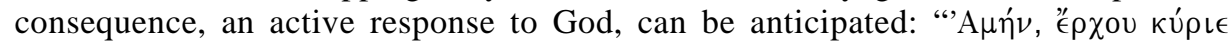
'I $ү \sigma 0 u$ " (22:20).

But the transforming power of the Apocalypse does not take place only because the narrative has a reversal strategy. How it succeeds further, in affecting the readers, is closely related to the external context of the Apocalypse.

\section{Transforming power of the Apocalypse in the external context}

As we have seen, a comparison of the beginning with the end of the Apocalypse allows us to identify the "reversal" or "inverted parallelism" in the narrative, which in part serves to transform the convictions of the readers/audience. If we remember, however, that the narrative is enacted in the socio-historical context of the readers/hearers, we obtain still more insight into this process of transformation.

\section{Three types of strategies which could bring about a change (of the audience) in the socio-historical context}

Each of the following three approaches offers some insight for understanding the transformative effect of the Apocalypse on John's contemporary Christians. The first and second methods, increasing the challenging forces and diminishing the opposing forces respectively, are suggested by Lewin (1961), while the third one is proposed by Van Gennep (1960) and deals with the dynamics of the liminal state in which a person passes through a temporary experience and is permanently changed as a result.

\section{Lewin's two methods}

Lewin (1961:235-238), secular theorist in behavioural change, identifies two basic means of initiating change in a person or group. Describing any static state as a balance of tension on either side of the status quo, Lewin postulates that a change in equilibrium can be achieved by two means: by increasing forces in the desired direction, or by reducing opposing forces. He adds that if a change from level L1 (the present level) to L2 (a new level) is brought about by increasing the forces toward L2, the secondary effects should be different from the case where the same change of level is brought about by diminishing the opposing forces. 
His two ways to bring about a change can be illustrated for each case of the static state, the first way increasing the tension and the second decreasing the tension (from left to right) as follows:

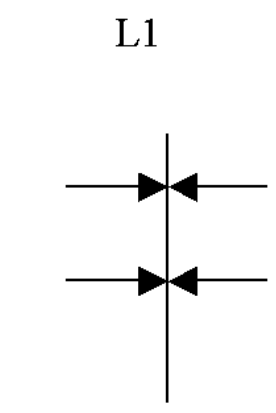

Static State

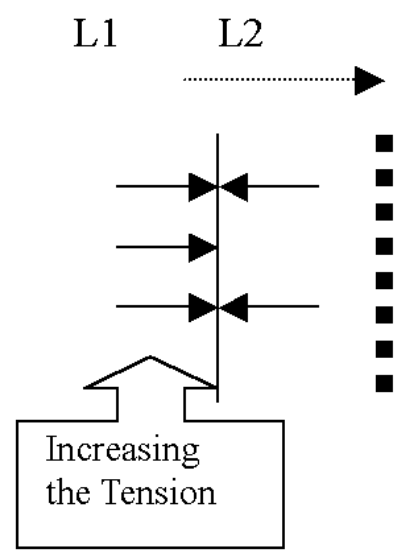

L1

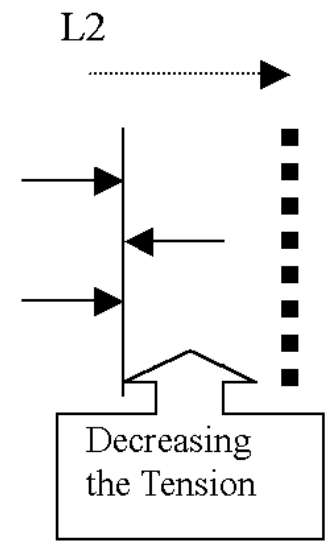

Fig. 2

While the equilibrium might change to the same new level in both cases, the secondary effect should, however, be quite different. In the first case, a fairly high degree of tension would accompany the process on the new level whereas in the second case, a state of relatively low level of tension would result. ${ }^{7}$ Lewin (1961:236) warns that in the first case, an increase of tension above a certain degree could lead to higher aggressiveness, higher emotionality, and lower constructiveness.

\section{Van Gennep's method}

While Lewin's two methods can be said to modulate the tension between the status quo and a new (desired) level, that is, to change the "understanding" of one's sociohistorical situation, Van Gennep's theory (1960) concerns an attempt to transform the individual, that is, "his/her essential self" like the change of one's identity in an initiation process.

Van Gennep holds that "all ceremonial patterns accompany a passage from one situation to another or from one cosmic or social world to another." Because of the importance of these transitions, he refers to them as rites of passage, a complete scheme which theoretically includes rites of separation, rites of transition, and rites of incorporation (1960:10-13). ${ }^{8}$

7. Schüssler Fiorenza's (1985) and Collins' (1984) approaches may accord with his first way (increasing forces in the desired direction), while Gager's (1975) may parallel the second case (reducing opposing forces).

8. They correspond to preliminal rites, liminal rites and postliminal rites respectively. For example, adolescence forms a liminal period between childhood and adulthood, but the passage from childhood 


\section{Approaches based on Lewin's first method (to transform the hearers by in- creasing the challenging forces)}

\section{Schüssler Fiorenza's approach (1985)}

Schüssler Fiorenza states that the symbolic language of the Apocalypse, as poetic language, evokes responses rather than defines meanings, so that "it becomes necessary for interpreters to acknowledge the ambiguity, openness, and indeterminacy of all literature" (1985:186). Arguing that there is a difference between fictional literature and historical writings, Schüssler Fiorenza suggests that the Apocalypse should perhaps be read as poetry, but the result of a literary analysis of the text should be complemented by a socio-historical analysis. For her, the historical situation (of tribulation and persecution) under Domitian is essential for grasping the rhetorical function of the book as one that strengthens endurance (1985:114). This is in spite of general agreement among scholars that there was no general persecution under Domitian, who was neither better nor worse than other Roman emperors. Schüssler Fiorenza (1985:181-199) argues that John tries to mobilize, persuade, and provoke Christians to stake their lives on the Lamb's followers. In this sense, her suggestion corresponds to Lewin's first strategy to make a change by increasing the tension (Lewin 1961:235-8).

\section{Collins' approach (1984)}

Collins, in contrast to Schüssler Fiorenza, does not view the Apocalypse as a response to political oppression or persecution. Factors such as personal background, temperament, and theological perspective are at least as important as aspects of the socio-historical situation (1984:105).

The task of Revelations was to overcome the unbearable tension perceived by the author between what was and what ought to have been. His purpose according to Collins, was to create that tension for readers unaware of it, to heighten it for those who felt it already, and then to overcome it in an act of literary imagination (1984:141$60)$, all of which corresponds to Lewin's first strategy to make a change by increasing the tension (1961:235-238).

For Collins the expressive language of the Apocalypse deals with the crisis of faith by providing a catharsis for its readers. Just as in the Greek tragedy where, with the help of language and symbols, certain emotions are aroused which then have to be purified by a literary catharsis, so the fears (for Rome) and grievances (about their situation) of the first readers of the Apocalypse are also rhetorically purified.

When read in such a manner, the Apocalypse offered Asian Christians an escape from reality by enabling them to experience the present as a time when religious hopes were realized. In such ways the symbolic world of the Apocalypse affected the behaviour and action of Christians in Asia Minor. "What ought to be was experienced as a present reality by the hearers in the linguistic and imaginative event of hearing the book read" (1984:154).

to adulthood involves a special series of rites of separation, a transition, and an incorporation into adulthood. On the other hand, rites of separation predominate at funeral ceremonies, rites of incorporation at marriages and transition rites in initiation (1960:11). 


\section{Approach based on Lewin's second way (to transform the hearers by diminishing the opposing forces)}

\section{Gager's approach (1975)}

Gager attempts to apply a structuralist understanding and analysis of myth to the composition of the Apocalypse. He maintains that the binary structure of myth is decisive in determining the structure or meaning of the book, in that it creates a machine for transcending time (1975:52). He states that the sections and patterns of the Apocalypse are all pressed into the binary structure of victory/hope and oppression/despair.

Gager also interprets the Apocalypse as a response to oppression and, more specifically, to persecution and martyrdom, and as a work that functions to console its readers and hearers (1975:50). This interpretation thus corresponds to Lewin's second way of effecting a change, namely, by decreasing the tension. The language and symbols of myth serve the purpose of softening the experience of conflict.

Firstly, the text oscillates between symbols of victory/hope and oppression/despair so that the reader gradually assumes that oppression and despair are penultimate. ${ }^{9}$ The oscillation serves to undermine any tendency among the audience to treat the conflicts in their experience as "permanent, unbearable contradictions" (1975:54). Secondly, as myth, the Apocalypse's structure serves to suppress time. Through "mythic narrative" the hearers experience future bliss in the present moment (1975:50). Drawing heavily on Levi-Strauss, Gager continues to say that, like the process of psychoanalysis, apocalyptic myths manipulate symbols so as to change the reality of the reader (1975:51). However, the suppression of time seems to be only illusory, because such a mythic enactment might not finally change the reality of Christian existence.

\section{Approach based on Van Gennep's model (to transform the hearers themselves through a liturgy)}

\section{Barr's approach (1998)}

Most scholars suppose that the Apocalypse must have been planned to be performed, as an oral recital of a story, in the liturgical context of Christian worship. Then we need to ask how such a narrative in such a context might influence the participants who hear it. $^{10}$

The primary setting for this story is a gathering of people at which someone reads John's narrative aloud, as a letter from John (1:3-4). This at least is the implied setting of the implied audience. Thompson (1990:69-73) carefully holds that the language of the Apocalypse is that of worship.

In order to interpret the transforming power of the Apocalypse according to Van Gennep's theory (1960), the boundary-crossing experience takes place in a liminal state. Hearing John's narrative in the context of worship may allow the readers/hearers to move from one stage to another. In the meanwhile, they experience a transitional stage,

9. For an example of the oscillation, the opening of the sixth seal (oppression/despair) is followed not by the seventh seal, but rather by a vision of the one hundred and forty-four thousand who bear the seal of God (victory/hope) (1975:54).

10. Barr (1998:179) suggests that there are two kinds of rituals: Some rituals serve to celebrate the world as it is and maintain the status quo - for example, various rites related to the emperor justify Roman rule. Other rituals serve to transform the world and one's identity. Weddings and initiation rites would be examples of such rites. 
a time when the participants can be changed into a new state. It is analogous to a boundary crossing from childhood to adulthood through a puberty ritual.

Hearing the book as liturgical material in the context of worship is like experiencing a series of rituals comprising of rites of "separation from the outside," "transition during participation in a worship" and "incorporation into the community (or the Lamb's followers)." The dynamics of this liminal state permit a person to pass through a temporary experience and to be permanently changed as a result. ${ }^{11}$

\section{Conclusion}

- In the most basic sense, an apocalypse is a story that removes the veil from ordinary reality and reveals what is truly happening. John's narrative aims to communicate to the audience his theological convictions about true "reality" behind all the events in their evil world, and to enable them to act in new ways. How much such a story can affect or transform its readers is in question. However, there is no doubt that it functioned to transform the imaginations of its first audience.

- Patte's and Lowry's studies bear out that John's narrative makes use of "reversal strategy" to transform the readers/hearers, which is done in the literary context. The reversal is to persuade the audience, which is related to the aim of John's narrative to transform the listeners' distorted view of a theme into a proper view. Insofar as it tries to persuade the audience, John's narrative can be called rhetoric.

- There are three opinions concerning the transformation of the audience in the external (socio-political) context. In order to change the "understanding" of one's socio-historical situation, Schüssler Fiorenza (1985) and Collins (1984) postulate that John tries to increase the tension in the desired direction, while Gager (1975) holds that the author tries to reduce opposing forces. The third suggestion of Barr (1998) states that the Apocalypse attempts to transform "one's essential self" as one changes one's identity in a initiation. In my opinion, each opinion reveals only one aspect of the rhetorical power that the Apocalypse wields upon the audience in the rhetorical situation, so that all three approaches should be honoured.

- The rhetoric turns the reader away from the misguided ideas of his/her current world to the heavenly perspective. As a result, the apocalypse rhetorically requests the Christian to witness to God's word until the end of the world, and the wayward to repent because the time is near. And finally, the transforming power of John's narrative in the literary and external context can be diagrammed as follows.

11. Barr (1998:180) holds that "one, passing through a rite, can be permanently altered." 
Socio-Rhetorical Situational Context

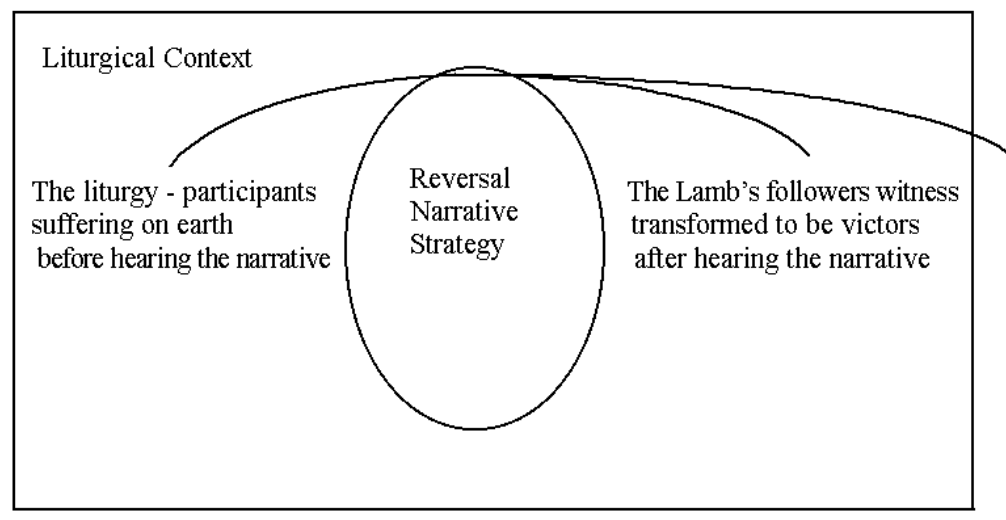




\section{BIBLIOGRAPHY}

Abrams, MH 1999. A Glossary of Literary Terms. Orlando, FL: Harcourt Brace College Pub.

Baldick, C 1990. The concise Oxford dictionary of Literary Terms. NY: Oxford Univ. Press.

Barr, DL 1998. Tales of the End: A Narrative Commentary on the Book of Revelation. Santa Rosa, CA: Polebridge Press.

Caird, GB 1966. The Revelation of St John the Divine. London:Black.

Collins, AY 1984. Crisis and Catharsis: The power of the Apocalypse. Philadelphia: Westminster.

Gager, J 1975. Kingdom and Community: The Social World of Early Christianity. Englewood Cliffs: Prentice-Hall.

Jang, Y 2001. A Narratological Approach to the Structure of the Apocalypse of John. Unpublished DTh dissertation, University of Stellenbosch, RSA.

Lewin, K 1961. Quasi-stationary Social Equilibria and the Problem of permanent Change, in Bennis, Benne, and Chin (ed), The Planning of Change, 235-238.

Lowry, EL 1980. The Homiletical Plot:The Sermon as Narrative Art Form. Atlanta: John Knox Press.

Patte, D 1990. Structural Exegesis for New Testament Critics. Minneapolis: Fortress Press.

Schüssler Fiorenza, ES 1985. The Book of Revelation: Justice and Judgment. Philadelphia: Fortress.

Thompson, L 1990. The book of Revelation: Apocalypse and Empire. New York: Oxford.

Van Gennep, A 1960. The Rites of Passage. Chicago: Universty of Chicago. 